\title{
The effect of selection and inbreeding on the ribonucleic acid content of mammary gland in mice
}

II. Effect of selection and inbreeding on the RNA/DNA ratio

\author{
SUNG YUNG-YI* \\ (Department of Animal Breeding, Faculty of Agriculture, \\ University of Tokyo, Bunkyo-ku, Tokyo) \\ (Received for Publication on September 8, 1969)
}

\begin{abstract}
Several works have been carried out to investigate into the factors relating to dairy performance and it was found that quantity and quality of the parenchyma of mammary gland might be major factors in the gland. Folley et al. $(1946)^{8)}$, NAITo et al. $(1955)^{144}$, Linzell $(1959)^{10}$, TURNER ${ }^{20)}$ and their colleagues ${ }^{19)}$ tried to find the indices of the quantity and quality of the parenchyma of mammary gland, and presented many papers which concerned to it. From these studies, the nucleic acid content of mammary gland can be an index of quantity and function of the parenchyma of mammary gland, because the desoxyribonucleic acid (DNA) content of nucleus in one cell is constant and the ribonucleic acid (RNA) is closely related to protein synthesis and also the ratio of RNA to DNA may indicate the secretory activity of mammary cell $1^{91}$.

To improve the milk yield, high DNA, RNA and RNA/DNA ratio are necessary ${ }^{18)}$, however, very few studies have been reported on the heritability of these indices. NAGAI et al. $(1957)^{18)}$ and YosidA $(1961)^{22}$ ) reported the heritabililty of the response of mammary development with synthetic hormone treatment at immature stage in mice was 0.5 , and ChrKamune (1961) ${ }^{2)}$ found tnat the heritability of DNA content of mammary gland was 0.2 in mice.

In ChiKamune's ${ }^{2)}$ observations, selection for the DNA content of mammary gland increased the DNA content with advancing generations and also RNA content increased, but the ratio of RNA to DNA decreased. It seems plausible that increase of the quantity of the parenchyma of mammary gland might bring increase of the total RNA of the gland though the ratio of RNA to DNA decreased with generations. It would be interesting whether it is possible to improve the mammary function through the selection for the ratio of RNA content to DNA.

Accordingly, the author tried to study the effect of selection and inbreeding on the RNA/ DNA ratio of mammary gland in mice.
\end{abstract}

\section{Materials and Methods}

All the animals used in selection study were outbred CFW strain mice. Eighteen female mice were adopted as the foundation stock. They were mated with full-sib males at random. After 20 days of the first parturition, they were mated again to make the second litter. The

* Present address: Department of Animal Husbandry, National Taiwan University, Roosevelt Rd., See. 4 Taipei Taiwan 
first litter size was adjusted to 7 females and 3 males per mother at birth and then to 6 females and 2 males on day 5 after parturition if possible. The second litter size was adjusted to 5 females and 5 males per mother at birth if possible and as much as possible to make 8 pupsper mother on day 5 after parturition in order to make the stimulation of suckling uniform and mothers were discarded if they did not maintain 8 pups in the second lactation. The body weight of mother and first litter were weighed every 5 days and those of second litter were weighed on $0,5,8,10$ and 12 days of postpartum.

The mothers were sacrificed on day 12 of the second lactation. The day 0 of lactation was day of parturition. Uterine weight and ovarian weight of both sides were weighed and the both sides of abdominal-inguinal mammary glands were removed, weighed and pooled in acetone. Then the mammary gland was extracted in a continuous extractor with alcohol at $90^{\circ} \mathrm{C}$ for $7-9$ hours followed by extraction with ether at $60^{\circ} \mathrm{C}$ for the similar time. These fat-extracted glands were weighed to determine the dried fat-free (D.F.F.) weight of mammary gland. After grinding these D.F.F. mammary glands into powder, the nucleic acid was extracted from them by the method of ScHNeIDER ${ }^{17 /}$, excepting the fat extraction step. DNA and RNA contents were determined following the YAGI's ${ }^{21)}$ modification of DISCHE'S ${ }^{31}$ and MEJBAuM's ${ }^{11}$ and the ratio of RNA to DNA was computed.

Selection was started in September, 1964 and had been continued to 13 th generation. Artificial selection was practiced at the first and second generations and then at every other generation. This selection was based entirely on individuals of higher DNA content than "mean minus standard deviation" and of high RNA/DNA ratio value. Thus, three mothers passing these criteria were selected and the pups at the first litter of these mothers were used as the parents of next generation. The second litters were discarded on day 12 owing to the sacrifice of the mothers.

The control group have been made from first generation which was inbred without selection for 9 generations. The data of 5 th, 6 th and 9 th generations of the control were estimated.

All experiments were completed in December, 1967.

Estimation of the effectiveness of selection were carried out on the significance of linear regression with generation of the experimental group (selected) in comparison with that of the control group. The variability of thes characters with generations were shown as the coefficients of variation (C.V.).

Management and environment of animals were in satisfactory condition. They were supplied water and "mouse cake" (manufactured by the Oriental East Co.) ad lib. and kept in the air conditioned animal room with the temperature of about $15-25^{\circ} \mathrm{C}$.

\section{Results and Discussion}

Changes of the various characters of mammary function with generations:

Changes of fresh and D.F.F. weight of mammary gland, total DNA-P, total RNA-P content, RNA-P/DNA-P ratio and the body weight of pups on day 12 after birth are shown in Table 1.

Linear regression on changes of these characters was not significant except the total RNA-P content. However, most of these changes were significant in consideration with the change of the control group, in order to eliminate the effect of inbreeding depression, if it existed. 
Select and inbreed on RNA/DNA of mammary gland

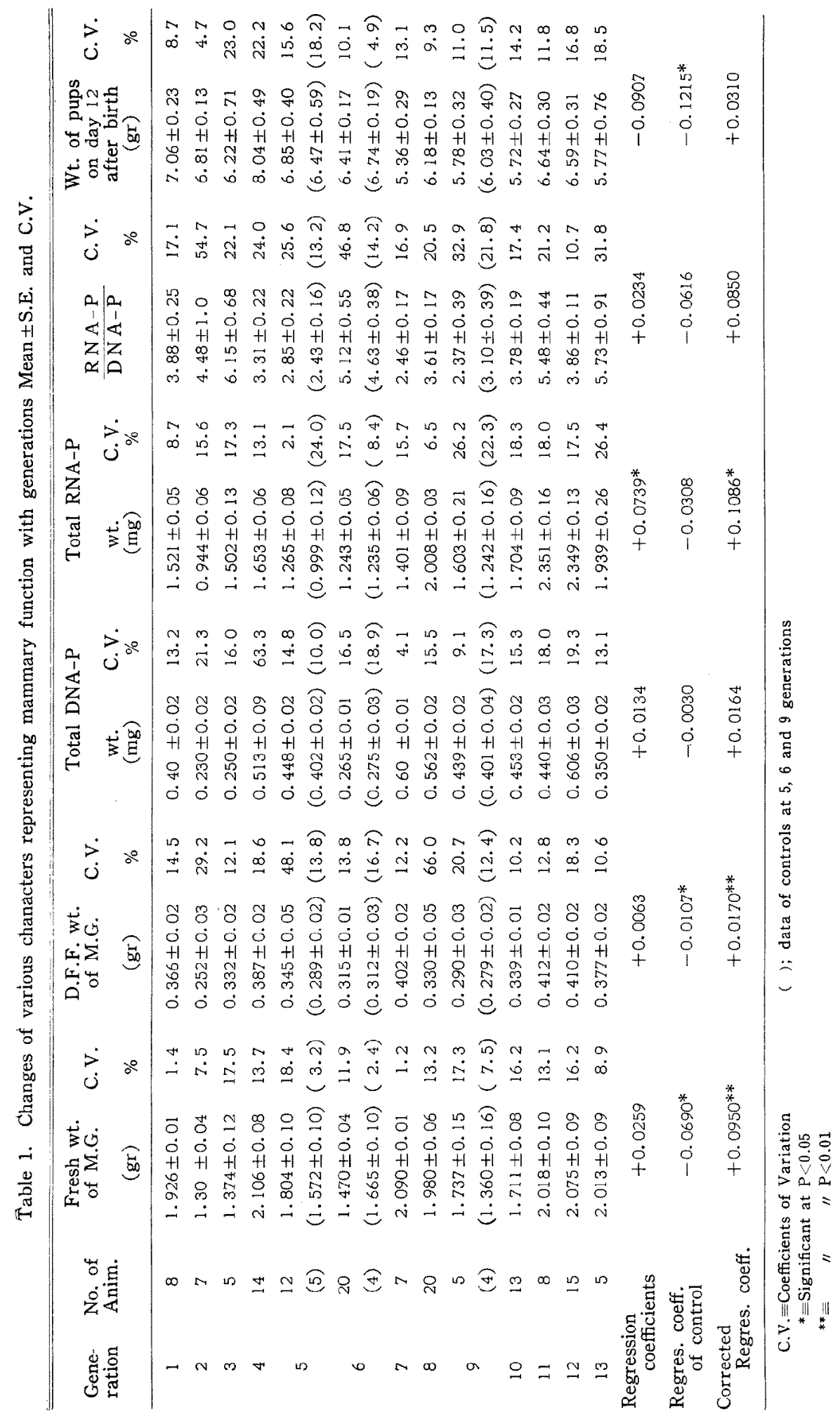


The fresh and D.F.F. weights of mammary gland seemed to increase slightly with generations as shown in Fig. 1.

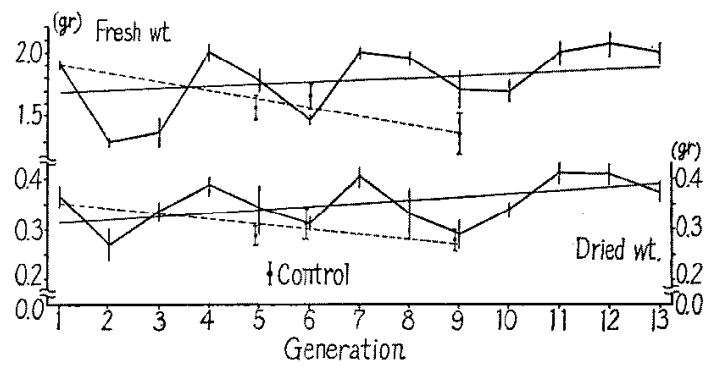

Fig. 1. Changes of the fresh and dried weights of mammary glands with generations

Change of total DNA-P content (Fig. 2) seemed to increase with generations, lacking significance. Even selection was based on DNA content higher than mean \pm s.d., selection differential of DNA content was estimated as $0.085 \mathrm{mg}$. on average of each generation and it was $19 \%$ of DNA contents. The reason why the increase of DNA is not so remarkable may be caused by the selection criterion having not so high value on DNA content.

NAITo (1958) ${ }^{15)}$ showed high correlation $(r=+0.95)$ between the number of cells per sight field and the DNA content per mg. dry weight in guinea-pig mammary gland, although MuNFoRD $(1963)^{12)}$ reported that correlation between level of DNA and histological measure of cell number was low in the mice mammary gland. In the present result, correlation between change of the DNA content and D.F.F. weight of mammary gland was highly significant $(r=+0.34-0.86)$.

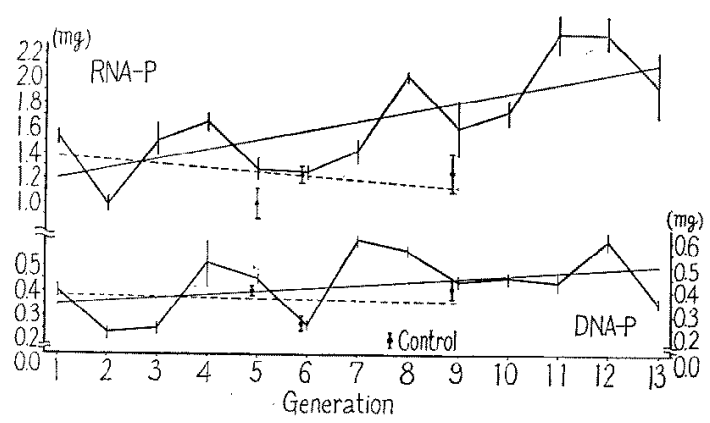

Fig. 2. Changes of total RNA-P and DNA-P contents of mammary glands with generations

There was a significant increase in the coefficient regression of the change of RNA-P content (Fig. 2) with generations.

The effect of selection and inbreeding on RNA/DNA ratio is shown in Fig. 3. Response to. selection until 13 th generation is shown in bold line and the accumulated selection differential is shown in hollow line. The proportion of selection was estimated as $40 \%$ throughout all generations. The regression coefficient of RNA/DNA is estimated as $b=+0.023$ which lacks 
Select and inbreed on RNA/DNA of mammary gland

significance. And it also lacks significance if it is corrected by that of control group considering the inbreeding depression.

The heritability of RNA/DNA of mammary gland was computed by applying the ratio of response to selection ${ }^{6,7)}$; the regression coefficient of response to selection was divided by the regression coefficient of the accumulated selection difference. The heritability was estimated as $\mathbf{h}^{2}=+0.0998$.

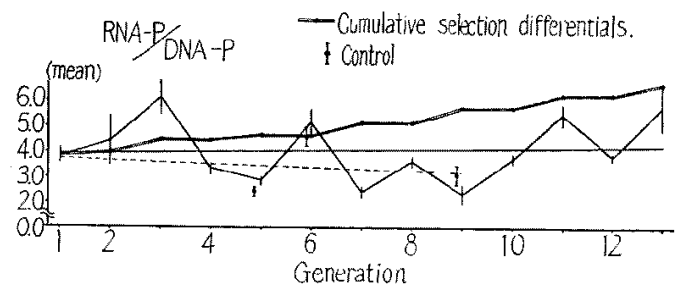

Fig. 3. Changes of RNA-P/DNA-P ratio of mammary glands with generations

This heritability about $10 \%$ seems to show that it is difficult to obtain easy validity of selection on the secretory activity of mammary cells. Narro (1960) ${ }^{16)}$ suggested that the heritability of the quantity and quality of the parenchyma of mammary gland might be high, but that of the secretory activity might be low. The present results showed this suggestion might be due and it might be necessary to begin with larger foundation population rich in variation in this character in order to obtain mice with high value on this character.

The body weight of pups on day 12 may be good index of mother's nursing ability (FALCONER $1947)^{4)}$. Body weight on day 12 of second litter seemed to decrease irrespective of the increase in the mammary function by selection. (Fig. 4). This phenomena may be caused by the fact that the selection was not on the body weight, and inbreeding depression in litter weight was more remarkable than the effect of increase in nursing ability of mothers.

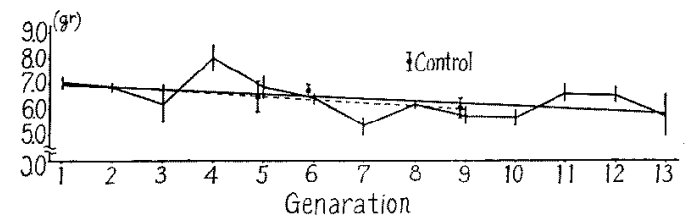

Fig. 4. Changes of weights of pups on day 12 after birth with generations

Change of the coefficient of variation with generations is not clear. It seemed that selection and inbreeding did not make the phenotype of these characters uniform. Particularly, coeff. cients of variation in mammary characters are larger than those of body weight characters. It indicates that the phenotype of the mammary characters is more liable to be influenced by environment than the body weight character. The fact that heritability of RNA/DNA is so lower than that of growth in mice (e.g., FALCONER \& LATYSZEWSKI, 1952) ${ }^{51}$ may bring the larger effect of the environment on them.

Changes of the various characters of mother with generations: 

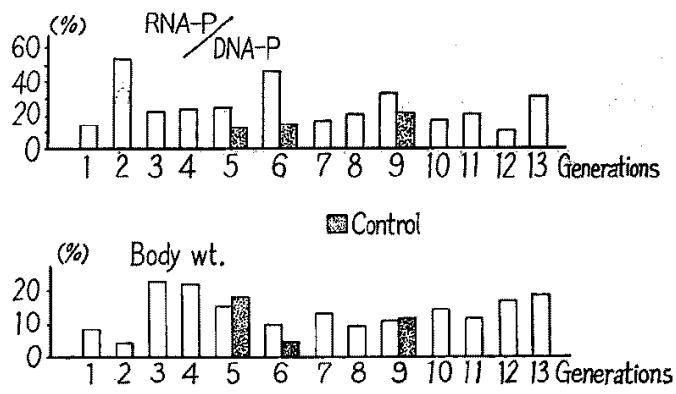

Fig. 5. Changes of coefficients of variation of RNA-P/DNA-P ratio of mammary glands (above) and body weights of pups on day 12 after birth (below) with generations

The various characters in mother were investigated. Changes of body weights at the first and second parturition and at sacrifice, the first and second litter size, ovarian weight and uterine weight are shown in Table 2. All of these changes seemed to decrease with generations, but they were not significant except the body weight at the second parturition. However, almost regression coefficients of these characters turn to positive if they are corrected by those of the control group. But most of them were not significant.

Even correlation between the body weight at the first and second parturition is high, the significant change with generations appears only at the second parturition. This may be the

Table 2. Changes of the various characters of mothers

\begin{tabular}{|c|c|c|c|c|c|c|c|}
\hline \multirow{2}{*}{ Generation } & \multirow{2}{*}{$\begin{array}{l}\text { No. of } \\
\text { Anim. }\end{array}$} & \multicolumn{6}{|c|}{ Body wt. (gr) } \\
\hline & & $\begin{array}{c}1 \text { st } \\
\text { Parturition }\end{array}$ & C.V. & $\begin{array}{c}\text { 2nd } \\
\text { Parturition }\end{array}$ & $\begin{array}{c}\text { C.V. } \\
\%\end{array}$ & Autopsy & $\begin{array}{c}\text { C.V. } \\
\%\end{array}$ \\
\hline 1 & 8 & $34.36 \pm 0.57$ & 4.4 & $41.23 \pm 0.83$ & 5.3 & $41.99 \pm 1.23$ & 7.9 \\
\hline 2 & 7 & $35.72 \pm 1.61$ & 12.8 & $38.30 \pm 1.07$ & 6.8 & $40.11 \pm 1.29$ & 7.9 \\
\hline 3 & 5 & $37.10 \pm 1.18$ & 9.0 & $38.37 \pm 1.18$ & 6.9 & $42.26 \pm 1.33$ & 6.3 \\
\hline 4 & 14 & $36.30 \pm 0.58$ & 7.5 & $42.73 \pm 0.79$ & 6.7 & $45.67 \pm 0.81$ & 6.4 \\
\hline 5 & $\begin{array}{c}12 \\
(5)\end{array}$ & $\begin{array}{c}35.86 \pm 1.41 \\
(33.40 \pm 0.93)\end{array}$ & $\begin{array}{l}10.4 \\
(7.4)\end{array}$ & $\begin{array}{c}41.43 \pm 0.85 \\
(33.40 \pm 0.86)\end{array}$ & $\begin{array}{l}5.4 \\
(5.1)\end{array}$ & $\begin{array}{c}44.0 \pm 0.83 \\
(42.34 \pm 0.52)\end{array}$ & $\begin{array}{c}4.6 \\
(2.5)\end{array}$ \\
\hline 6 & $\begin{array}{l}20 \\
(4)\end{array}$ & $\begin{array}{c}35.16 \pm 0.63 \\
(32.48 \pm 1.16)\end{array}$ & $\begin{array}{c}6.7 \\
(6.2)\end{array}$ & $\begin{array}{c}41.10 \pm 0.61 \\
(37.0 \pm 0.86)\end{array}$ & $\begin{array}{l}5.8 \\
(4.0)\end{array}$ & $\begin{array}{c}41.78 \pm 0.83 \\
(41.63 \pm 2.07)\end{array}$ & $\begin{array}{c}7.5 \\
(8.6)\end{array}$ \\
\hline 7 & 7 & $35.63 \pm 0.84$ & 6.7 & $41.36 \pm 1.34$ & 8.5 & $45.80 \pm 1.13$ & 5.3 \\
\hline 8 & 20 & $32.48 \pm 0.66$ & 1.2 & $39.36 \pm 0.70$ & 8.2 & $43.25 \pm 0.65$ & 6.5 \\
\hline 9 & $\begin{array}{c}5 \\
(4)\end{array}$ & $\begin{array}{c}31.18 \pm 1.40 \\
(32.50 \pm 1.04)\end{array}$ & $\begin{array}{l}11.9 \\
(5.5)\end{array}$ & $\begin{array}{c}36.30 \pm 1.17 \\
(34.20 \pm 1.09)\end{array}$ & $\begin{array}{c}6.5 \\
(5.5)\end{array}$ & $\begin{array}{c}38.43 \pm 1.79 \\
(38.70 \pm 1.41)\end{array}$ & $\begin{array}{c}7.2 \\
(6.3)\end{array}$ \\
\hline 10 & 13 & $33.78 \pm 0.75$ & 7.7 & $38.93 \pm 1.10$ & 8.9 & $39.24 \pm 0.77$ & 5.6 \\
\hline 11 & 8 & $35.01 \pm 0.67$ & 4.9 & $39.45 \pm 0.29$ & 2.3 & $43.54 \pm 0.96$ & 5.8 \\
\hline 12 & 15 & $34.80 \pm 1.02$ & 8.3 & $39.35 \pm 0.98$ & 9.3 & $44.30 \pm 0.77$ & 6.5 \\
\hline 13 & 5 & $32.58 \pm 0.98$ & 9.5 & $36.91 \pm 1.11$ & 7.4 & $40.24 \pm 1.42$ & 7.1 \\
\hline \multicolumn{2}{|c|}{ Regression coefficient } & \multicolumn{2}{|l|}{-0.2376} & \multicolumn{2}{|c|}{$-0.2932^{*}$} & \multicolumn{2}{|l|}{+0.0012} \\
\hline \multicolumn{2}{|c|}{ Regres. coeff. of control } & \multicolumn{2}{|l|}{-0.2487} & \multicolumn{2}{|l|}{-0.9160} & \multicolumn{2}{|l|}{-0.2917} \\
\hline \multicolumn{2}{|c|}{ Corrected Regres. coeff. } & \multicolumn{2}{|l|}{+0.0110} & \multicolumn{2}{|l|}{$+0.620^{*}$} & \multicolumn{2}{|l|}{+0.2927} \\
\hline
\end{tabular}

( ); data of controls at 5, 6 and 9 generations

* Significant at $\mathrm{P}<0.05$ 
Select and inbreed on RNA/DNA of mammary gland

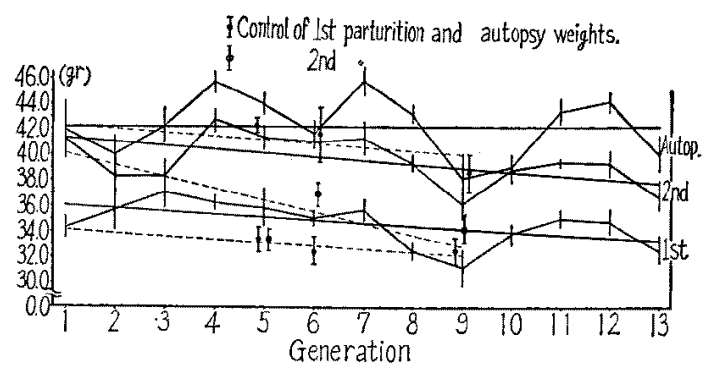

Fig. 6. Changes of body weights of mothers at the first and second parturitions and autopsy with generations

cause of that the differences between the first and second parturition weight at the early generations were large but decreased with generations. The reason why it declined with generations was unknown.

The slight increase with generations of body weight of mother at sacrifice seemed to relate indirectly to the increase of mammary function.

Although it was reported that litter size declined by inbreeding (Bowman and Falconer, $1960)^{11}$, the decrease of litter size by succession of selection and inbreeding was not clear in this experiment. It seemed probable that selection on mammary function had indirect influence on the increase of fertillty.

Coefficients of variation of litter size, ovarian weight and uterine weight are larger than

with generations Mean \pm S.E. and Coefficients of Variation

\begin{tabular}{|c|c|c|c|c|c|c|c|}
\hline \multicolumn{4}{|c|}{ Litter size (Mean) } & \multicolumn{2}{|c|}{ Ovarian wt. } & \multicolumn{2}{|c|}{ Uterine wt. } \\
\hline 1 st & $\begin{array}{c}\text { C.V. } \\
\%\end{array}$ & $2 \mathrm{nd}$ & $\begin{array}{c}\text { C.V. } \\
\%\end{array}$ & $(\mathrm{mg})$ & C.V. & & C.V. \\
\hline $8.8 \pm 0.77$ & 23.4 & $13.8 \pm 0.75$ & 14.4 & $9.84 \pm 0.81$ & 33.7 & $113.1 \pm 24.6$ & 57.5 \\
\hline $10.8 \pm 0.57$ & 15.0 & $13.9 \pm 0.71$ & 12.5 & $8.57 \pm 0.52$ & 21.8 & $124.5 \pm 9.1$ & 18.0 \\
\hline $9.2 \pm 0.93$ & 28.3 & $9.8 \pm 1.11$ & 25.2 & $11.15 \pm 0.53$ & 14.2 & $123.6 \pm 12.7$ & 20.4 \\
\hline $11.4 \pm 0.50$ & 20.7 & $9.5 \pm 0.61$ & 23.1 & $10.33 \pm 0.97$ & 48.5 & $166.6 \pm 11.6$ & 25.1 \\
\hline $9.4 \pm 0.93$ & 26.1 & $10.1 \pm 1.23$ & 32.2 & $10.15 \pm 1.03$ & 24.9 & $175.0 \pm 17,2$ & 24.0 \\
\hline$(6.8 \pm 1.07)$ & $(31.5)$ & $(3.0 \pm 1.26)$ & $(84.0)$ & $(9.60 \pm 0.55)$ & $(4.5)$ & $(113.9+6.7)$ & $(10.2)$ \\
\hline $10.5 \pm 0.51$ & 18.7 & $13.7 \pm 0.50$ & 14.1 & $11.08 \pm 0.82$ & 27.7 & $136.1 \pm 5.3$ & 18.5 \\
\hline$(6.5 \pm 1.55)$ & $(41.3)$ & $(10.5 \pm 0.87)$ & $(14.4)$ & $(10.63 \pm 0.60)$ & $(9.8)$ & $(147.8 \pm 22.6)$ & $(26.5)$ \\
\hline $11.0 \pm 0.79$ & 21.5 & $12.6 \pm 0.71$ & 14.8 & $10.0 \pm 0.67$ & 23.9 & $121.5 \pm 3.7$ & 7.0 \\
\hline $10.2 \pm 0.27$ & 14.4 & $11.2 \pm 0.53$ & 21.8 & $9.98 \pm 0.37$ & 23.2 & $134.1 \pm 7.3$ & 23.7 \\
\hline $8.0 \pm 0.54$ & 17.7 & $8.2 \pm 1.24$ & 30.3 & $7.75 \pm 0.75$ & 25.6 & $119.1 \pm 5.9$ & 8.6 \\
\hline$(5.8 \pm 1.16)$ & $(34.6)$ & $(5.0 \pm 0.91)$ & $(31.5)$ & $(7.75 \pm 0.25)$ & $(5.6)$ & $(130.0 \pm 5.9)$ & $(7.9)$ \\
\hline $9.5 \pm 0.63$ & 23.0 & $10.3 \pm 1.21$ & 37.4 & $7.97 \pm 0.62$ & 32.1 & $137.1 \pm 18.0$ & 37.1 \\
\hline $9.9 \pm 0.98$ & 28.0 & $10.7 \pm 0.90$ & 26.4 & $10.16 \pm 0.56$ & 21.4 & $129.0 \pm 4.1$ & 8.3 \\
\hline $11.8 \pm 0.63$ & 16.0 & $9.7 \pm 1.33$ & 50.9 & $10.37 \pm 0.36$ & 18.8 & $132.9 \pm 6.4$ & 18.1 \\
\hline $10.5 \pm 0.37$ & 12.1 & $10.1 \pm 1.37$ & 33.1 & $9.43 \pm 0.68$ & 19.1 & $101.9 \pm 13.8$ & 23.4 \\
\hline \multicolumn{2}{|l|}{+0.0538} & \multicolumn{2}{|c|}{-0.2347} & \multicolumn{2}{|c|}{-0.0575} & \multicolumn{2}{|c|}{-1.1308} \\
\hline \multicolumn{2}{|l|}{-0.3714} & \multicolumn{2}{|c|}{-0.4428} & \multicolumn{2}{|c|}{-0.2199} & \multicolumn{2}{|c|}{+2.7236} \\
\hline \multicolumn{2}{|l|}{-0.3177} & \multicolumn{2}{|c|}{+0.2080} & \multicolumn{2}{|c|}{$+0.1626^{*}$} & \multicolumn{2}{|c|}{-3.8520} \\
\hline
\end{tabular}




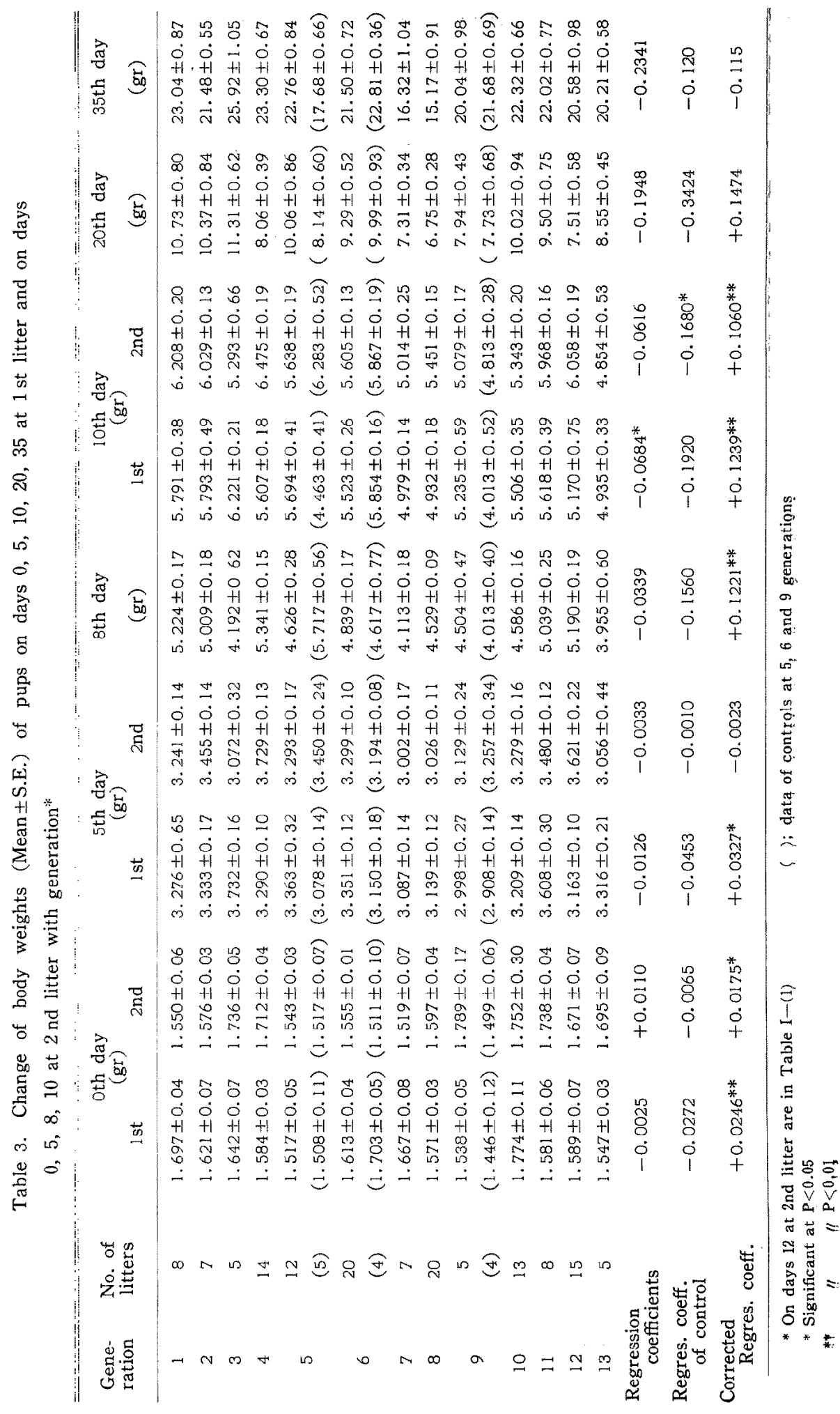


the body weight characters. The phenotype of litter size is also one of the characters with considerable complexity. It is not only influenced by inbreeding depression but the number of shed ova, number of fertilized ova and the number of zygotes carried to term and reproductive physiological characters.

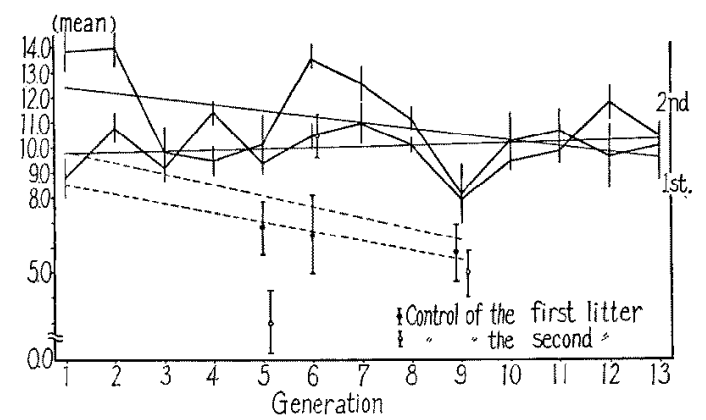

Fig. 7. Changes of litter size at the first and second parturitions with generations

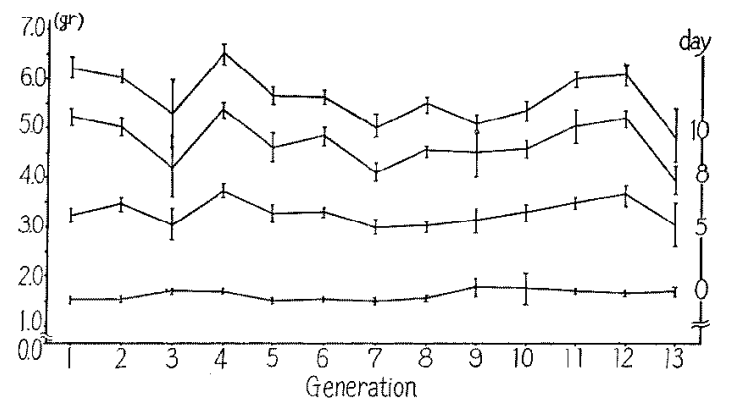

Fig. 8. Changes of body weights of pups on days $0,5,8$ and 10 at the second litter with generations

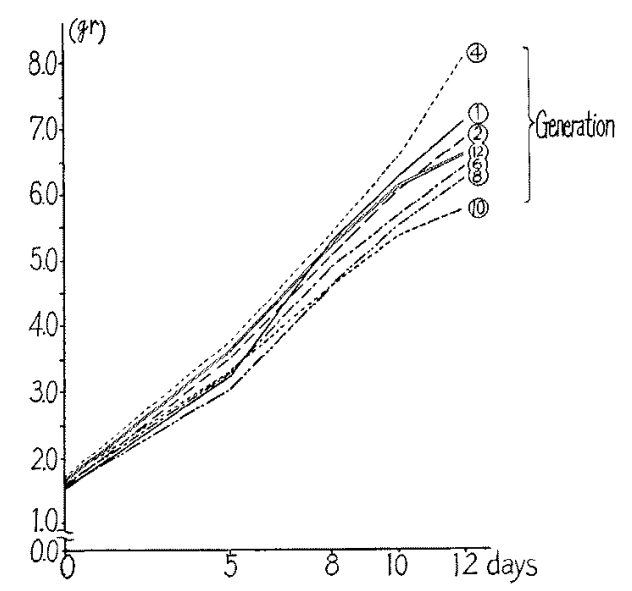

Fig. 9. Growth curve body weights of pups at the second litter in several generations 
Changes of body weights of pups with generations:

Changes of body weights of pups by selection and inbreeding on mammary function were shown in Table 3 . The body weight in the first litter was analysed on days $0,5,10,20$ and 35 and on days $0,5,8,10,12$ at the second litter. (Fig. 8, 9). All of these showed a tendency to decrease generation after generation but lacked significance even the inbreeding: depression had influenced on them. This indicates that improvement of the function of mammary gland avoided more or less the decrease of litter weight which was affected by inbreeding depression. But in Fig.9, it seemed clear that growth curves of body weight of the second. litter at the earlier generations were better than those of the later generations. Significant decrease in those on day 10 seemed to show the weakness of litter's sucking ability by the inbreeding depression rather than decrease of milk secretion of mothers.

\section{Summary}

The effect of selection and inbreeding on the RNA/DNA ratio of mammary gland was. studied. Adopting outbred CFW strain mice as a foundation stock, selection and full-sib mating were carried out until 13 th generation. The results are briefly summarized as follows.

1) Changes of fresh and D.F.F. weights of mammary gland, total DNA and RNA contents. and RNA/DNA ratio were seemed to increase slightly with generations but linear regressions on changes of these characters were not significant except the total RNA content. However, most of these changes were significant in cosideration with the control group to eliminate the effect of inbreeding depression.

The heritability of RNA/DNA ratio of mammary gland was computed by applying the: ratio of response to selection. It was estimated as $h^{2}=+0.0998$ and it seemed difficult to obtain easy validity of selection owing to the larger effect of environment on them.

2) The decrease of litter size by succession of selection and inbreeding was not clear in. this experiment. It seemed probable that selection on mammary function had indirect influence on the increase of the fertility.

Changes of various characters in mother with generations were estimated and discussed. All of these changes seemed to decrease with generations, but they were not significant except the second parturition weight, however, almost all of the regression coefficients of these characters. turn to positive if they are corrected by those of the cotrol group. But they also lack significance.

3) Change of body weight of pups showed a tendency to decrease with generations but they lacked significance. This seems to indicate that improving the mammary function may be: avoided more or less the decrease of litter weight which was affected by inbreeding depression.

4) It was clear that the character of mammary function was more complicated than body weight character in comparison with those of coefficients of variation.

\section{Acknowledgment}

The author wish to express his hearty thanks to Prof. Dr. M. Narto, Associate Prof. Y. ShodA and Assistant Prof. Dr. K. Конмото of Department of Animal Breeding at the University of Tokyo, for their supports and advices throughtout the work, and also thanks to the colleagues. who helped to keep mice in good conditions.

Some parts of data of this report were presented as the doctoral thesis at the University of Tokyo. 


\section{References}

1) Bowman, J.C. and D.S. Falconer (1960) Genet. Res., I: 262-274.

2) Chikamune, T. (1961) Doctoral Thesis, Tokyo Univ. Fac. Agric. (in Japanese)

3) Dische, Z. (1930) Mikrochemie, 8: 4.

4) Falconer, D.S. (1947) J. Agric. Sci., 37: 224-235.

5) Falconer, D.S. and M. LATYszewski (1952) J. Genet., 51: 67-80.

6) FALConer, D.S. (1953) J. Genet., 51: 470-501.

7) Falconer, D.S. (1960) Introduction to quantitative genentics.: 186-207. Oliver and Boyd, Edinburgh and London.

8) Folley, S.J. and A.L. Greenbaum (1946) Biochem. J., 40: 46-51.

9) Kirkham, W.R. and C.W. Turner (1953) Proc. Soc. Exp. Biol. and Med., 83: 123-126.

10) Linzell, J.L. (1959) Physiol. Rev., 39: 534-576.

11) Mеjваuм, W. (1939) Z. Physiol. Chem., 258: 117-120.

12) Munford, R.E. (1963) J. Endocrin., 28: 35-44.

13) NagAi, J., M. Yosida and M. Naito (1957) Jap. J. Zootech. Sci., 28: (supll) 4. (in Japanese)

14) Naito, M., Y. Shoda and J. NAgai (1955) Endocrinol. Jap., 2: 205-220.

15) Narto, M. (1958) J. Dairy Res., 25: 17-23.

16) NaIto, M. (1960) Animal Breeding.: 83-84. Yokendo, Tokyo. (in Japanese)

17) Schneider, W.C. (1945) J. Biol. Chem., 161: 293-303.

18) Sung, Y.Y. (1967) Jap. J. Zootech. Sci., 38: 328-333. (in Japaness)

19) Tucker, H.A. and R.P. ReECE (1962) Proc. Soc. Exp. Biol. and Med., 111: 639-642.

20) TURNER, C.W. (1959) Res. Bull. Mo. agric. Exp. Stn. No. 697.

21) YAGI, Y. (1951) Nucleic acids and nucleoproteins, 1: 140-141. Kyoritu, Tokyo. (in Japanese)

22) Yosida, M. (1961) Jap. J. Zootech. Sci., 32: 125-133. 


\title{
マウス乳腺の核酸とくにリボ核酸量におよにす選抜近交の効果 \\ II. 乳腺の RNA/DNA 比の選抜の勃果
}

\author{
宋永義 \\ (東京大学農学部)
}

泌乳㙨能の改良の指標として乳腺の核酸县を取り上 げその RNA/DNA 比に対する13世代にわたる選抜 近交の效果ををこめた。

供試動物は非近交 CFW 系マウスで，饺配は兄妹交配

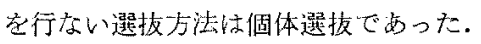

まず第 2 産次泌乳第 12 日令の母鼠ソケイ部乳腺を左 在比分け琛取，核酸学抽出測定，その総 DNA 合量が世 代内 mean-s.d. 以上でかつ RNA/DNA 比が高いるの

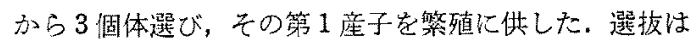
第 1 ，2世代に行ない引繶き，第 $4 ， 6 \cdots 12$ 世代と偶数世 代に実施した。

な子対照区として同じ基礎集団から選抜をせずに近交 の文行なったマウス群をとった。

符 13 世代までの結果を要䄪すると

1) 泌烈関保形質の累代変化について

新鮮乳腺重量, 脱脂乾燥椤腺重量, 総 DNA 量, 総 RNA 量, RNA/DNA 比の世代に対する回帰法いずれ も正の回帰であったが有意性を示したのはRNA 量のみ であった。しかしそれら諸形質を対照区での近交退化の

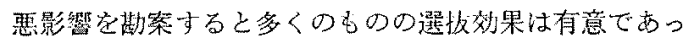
t.

RNA/DNA 比の望伝率花比代平均回帰之選拔差の累
積回帰の比で求めた結果 $\mathrm{h}^{2}=0.0998$ でふなり低く，㖟 境の影響が強く出，交た近交の悪影響定受けやすいこと が判った。

2）母における関連形質の変化について

母体重の変化江負の回㴆を示したが，対照とした非選 拔近交系での回帰を考虑に入れるとその回帰性正の变化 示した.

一腹子数の減小怡有意でなかった．これは乳腺機能に 対する選报は間接的に繁殖関係の形質によい影響をあた えているのではないかと考えられる。

3）子体雷の変化について

初産次子体重党 $0,5,10,20,25$ 日命, 2 産次注 0 , $5 ， 8 ， 10 ， 12$ 日令に測定したが，近交退化の現象が見ら れ累代的に減小の倾向を示した。 乙かし有意の減小を示 したのは10日令体重であった，乳腺機能の選坊による 泌乳の堌加は近交による子体重の減小をある程度補償し ているが10日令で时哺乳力が弱いため子体重の低下が 影藷に出るのではないかと考方られる。

諸形質の成續を綜合的に考无ると，泌乳機能の選拔近

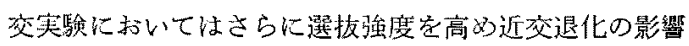
を除去できればその約果住さらに明らかになるのではな いか人考えられる。 